\title{
Fossil seaward-dipping reflector sequences preserved in southeastern Australia: a 600 Ma volcanic passive margin in eastern Gondwanaland
}

\author{
NICHOLAS G. DIREEN ${ }^{1,2}$ \& ANTHONY J. CRAWFORD ${ }^{1}$ \\ ${ }^{1}$ Centre for Ore Deposit Research, University of Tasmania, GPO Box 252-79, Hobart, Tas. 7001, Australia \\ ${ }^{2}$ Present address: Continental Evolution Research Group, University of Adelaide, Adelaide, S.A. 5005, Australia \\ (e-mail: Nick.Direen@adelaide.edu.au)
}

\begin{abstract}
Evidence for a c. 600 Ma rifted passive margin in eastern Australia exists in the form of multiple belts of mafic volcanic rocks preserved along the western margin of the Tasman Fold Belt System, and giving rise to elongate magnetic anomalies. Outcrop, drillhole and geophysical evidence points to piles of lavas, volcaniclastic and intrusive rocks up to $6 \mathrm{~km}$ thick, extending for strike lengths of hundreds of kilometres in individual segments. The distinctive, unifying characteristics of these piles are apparent common formation ages (600-580 Ma), presence of early more landward transitional alkaline basalts, and more seaward abundant rift tholeiites, with high-temperature picrites and olivine-rich basalts at most localities. Despite later structural reorganization, these belts have close geochemical, geometric and lithological affinities with Mesozoic seaward-dipping reflector sequences along the North Atlantic, and northwestern Australian volcanic passive margins, and strongly imply the formation of a volcanic passive margin in eastern Gondwanaland at the close of the Neoproterozoic. Recognition of this event has implications for the position of an implied earlier rifted margin related to the break-up of Rodinia around $780 \mathrm{Ma}$. A rifting event at $600 \mathrm{Ma}$ in eastern Gondwanaland helps explain both the lack of evidence for volcanism from Rodinia break-up, and a widespread $600 \mathrm{Ma}$ population of inherited zircons within rocks of the Lachlan Orogen, which developed outboard of the passive margin in earliest Palaeozoic time.
\end{abstract}

Keywords: Eastern Australia, Neoproterozoic, Rodinia, seaward-dipping reflector sequences, basalts.

Detailed seismic studies over the last decade have demonstrated important variability in the morphotectonic nature of passive margins. These variations in crustal architecture should exert a major control on the response to collision between a passive margin and an arc, and on the nature of any fold belt so generated. A first-order difference between modern passive margins is the presence or absence of significant magmatism leading up to, and accompanying ocean opening. Volcanic passive margins are characterized by voluminous basalt-dominated magmatic piles that formed around the time of break-up (Planke et al. 2000). For example, more than half the length of the South Atlantic continental margins appears to be marked by Mesozoic basalt-dominated seaward-dipping reflector sequences (SDRS) (Gladczenko et al. 1997). These SDRS usually broadly parallel the continental margin. In contrast, non-volcanic passive margins, such as the southern margin of Australia, show a very broad zone of pre-break-up extension, but limited magmatism during break-up (Sayers et al. 2001).

We presume that a fold belt generated by arc-continent collision involving a volcanic passive margin with SDRS might be structurally and geophysically very different from that produced by arc collision with a non-volcanic passive margin. This raises the question of whether modified ancient SDRS can be identified in pre-Tertiary fold belts. To our knowledge, none has been identified to date, although a similar pile of Proterozoic basalts, including primitive picritic lavas, described from the Cape Smith Belt of Quebec (Francis et al. 1983; St-Onge et al. 1999) may also represent fossilized SDRS that have not hitherto been recognized as such.

In this paper, we describe evidence for an ancient volcanic passive margin, including thick volcanic sequences resembling Mesozoic SDRS, formed at c. $600 \mathrm{Ma}$ during fragmentation of the eastern margin of proto-Gondwanaland. Rocks forming this latest Neoproterozoic margin occur as disrupted and discontinuous basalt-dominated packages over a strike length of $>3000 \mathrm{~km}$ in southeastern Australia, usually associated with shallow marine sedimentary rocks. In many places, they were overthrust at c. $510 \mathrm{Ma}$ by boninite-dominated allochthons derived from the forearc region of a colliding Early Cambrian intra-oceanic arc (Crawford \& Berry 1992).

The strong evidence (Veevers et al. 1997; Veevers 2000; Foden et al. 2001) that Gondwanaland experienced a major break-up event at c. $600 \mathrm{Ma}$ contrasts with the sparse magmatic record for the break-up of Rodinia, which is believed, on the basis of palaeomagnetic evidence ( $\mathrm{Li} \&$ Powell 2001; Wingate et al. 2001), to have occurred along this same margin between $c$. $827 \mathrm{Ma}$ and $780 \mathrm{Ma}$. Here, we review the evidence for a major volcanic passive margin-forming event at c. $600 \mathrm{Ma}$, and speculate on the whereabouts of the evidence for the earlier $780 \mathrm{Ma}$ event.

\section{Characteristics of modern seaward-dipping reflector sequences}

There are three comparatively well-studied Mesozoic-Paleogene volcanic passive margins on the modern Earth: the conjugate Møre-Vøring-East Greenland margins (Larsen et al. 1998; Mjelde et al. 2001) and the Gascoyne-Cuvier margin off Western Australia (Colwell et al. 1994; Symonds et al. 1998). Most information about these margins is remotely sensed from a combination of multi-channel seismic (MCS), ocean bottom seismometer, gravity and magnetic data, with limited 'groundtruth' coming from sparse dredging and drilling (Ocean Drilling Program (ODP) Sites 642, 765, 915, 917, 918, 989 and 990: 
Eldholm et al. 1989; Exon et al. 1992; Larsen et al. 1994; Fitton et al. 2000). Knowledge of SDRS on other margins is from remotely sensed data alone, principally MCS and magnetic data (e.g. Talwani et al. 1995; Gladczenko et al. 1997; Barker 1999).

Geometrically, SDRS form long (200-400 km), wide (40$100 \mathrm{~km}$ ), wedges up to $10 \mathrm{~km}$ thick, that roughly parallel the continent-ocean boundary (COB) at its inboard edge, usually in multiple rift sectors (Fig. 1b) (Planke et al. 2000). These wedges overlie highly thinned, normal-faulted continental crust (Skogseid et al. 1992; Symonds et al. 1998). Where buried under later sediments, SDRS are detectable by MCS data as thick packets of continuous, high-amplitude reflections, with high velocities $\left(>7 \mathrm{~km} \mathrm{~s}^{-1}\right.$ ) (Talwani et al. 1995; Symonds et al. 1998). They are also marked by coincident high-amplitude (500-1000 nT) magnetic anomalies, with characteristic asymmetry, tailing off from the COB (Talwani et al. 1995; Barker 1999). SDRS are also associated with free-air gravity highs of up to $500 \mu \mathrm{m} \mathrm{s}^{-2}$ (Larsen et al. 1998; Barker 1999).

Limited drilling of SDRS shows they consist inboard of stacked, massive, subaerial lava flows with minor interflow sediments, often altered volcaniclastic rocks or marginal marine in nature. Seaward, SDRS comprise stacked, pillowed lavas, flows and shallow sills extruded onto and emplaced into marine sediments (e.g.Viereck et al. 1988). The potential field anomalies associated with SDRS arise from measured magnetic susceptibilities on basaltic lavas averaging between 1000 and $5000 \times$ $10^{-5} \mathrm{SI}$, and densities of around $(2.8-3.0) \times 10^{3} \mathrm{~kg} \mathrm{~m}^{-3}$ (Eldholm et al. 1989; Planke et al. 1999).

Petrologically and geochemically, the lavas are overwhelmingly dominated by normal mid-ocean ridge basalt (N-MORB) tholeiites, with minor dacite and andesite derived from crustal melting and assimilation (Viereck et al. 1988; Crawford \& von Rad 1994). The N-MORB tholeiites often show strong light rare earth element (LREE) depletion (Ludden \& Dionne 1992; Saunders et al. 1997). An additional unifying feature of SDRS packages is the presence of widespread subaerial to shallow marine picritic lavas (e.g. Saunders et al. 1997).

\section{Late Neoproterozoic volcanic rocks in southeastern Australia}

Late Neoproterozoic volcanic rocks occur in three elongate belts in the Delamerian Orogen (Fig. 1a) of southeastern Australia, and are best exposed in western New South Wales and Tasmania. Major long-wavelength gravity and magnetic highs under the Cambrian Warburton Basin represent a further likely subsurface extension (Meixner et al. 1999).

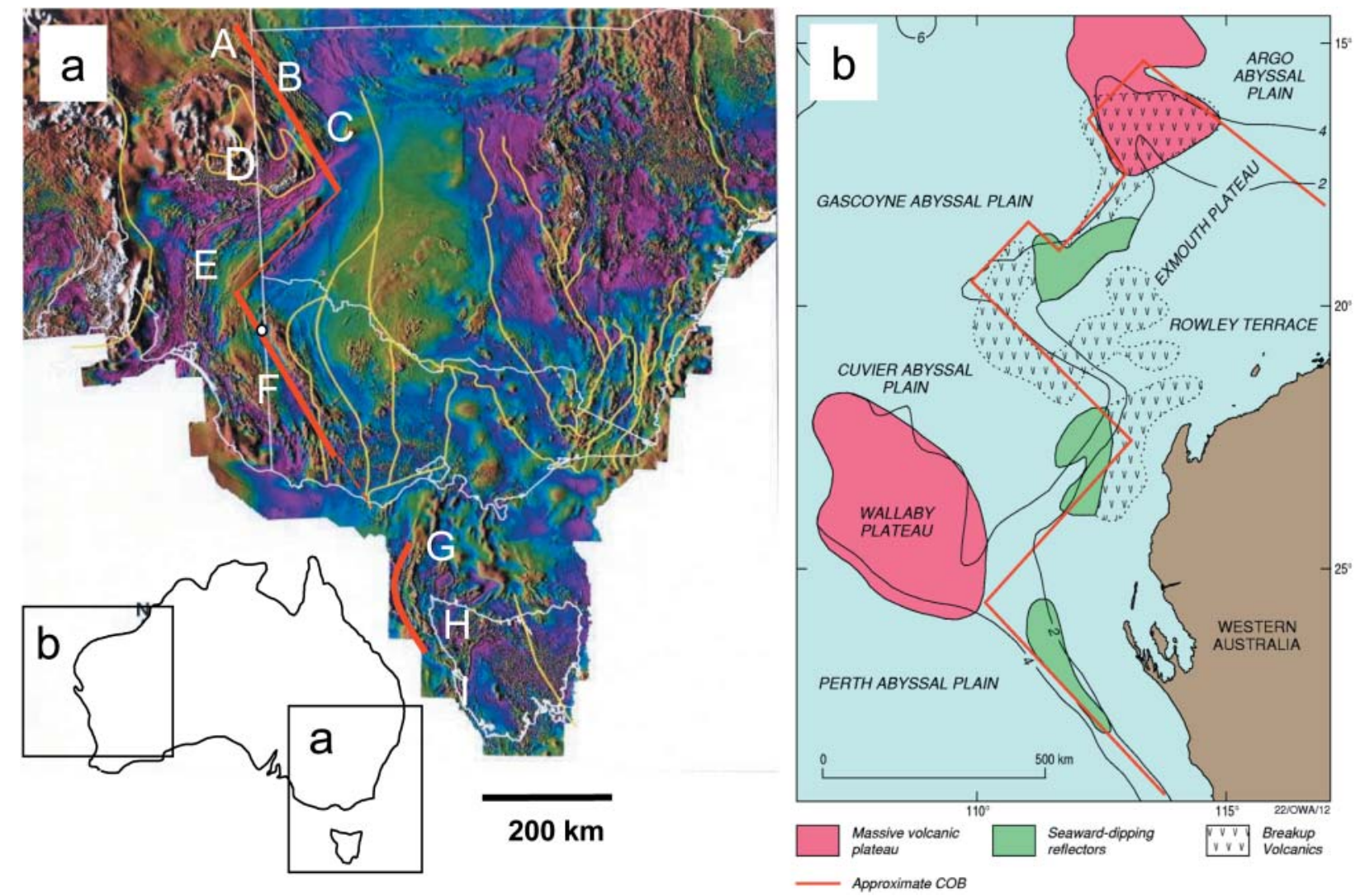

Fig. 1. (a) Total magnetic intensity image of southeastern Australia, with red high-blue low colour stretch (compilation: Geological Survey of Victoria; used with permission. Data from Geological Survey of Victoria, Geoscience Australia, Mineral Resources NSW, Primary Industries \& Resources SA, Mineral Resources Tasmania, and industry surveys). High-amplitude magnetic anomalies attributed to east-facing Neoproterozoic fossil SDRS shown with red line. Australian state borders and coastline shown in white. Tectonic domains from VandenBerg et al. (2000) shown in yellow. A, Murteree-Jena area of Warburton Basin; B, Mt Arrowsmith, Koonenberry Belt; C, Mt Wright, Koonenberry Belt; D, Mesoproterozoic Curnamona Province (Broken Hill Block); E, Truro, Adelaide Fold Belt; F, Dimboola Subzone; G, King Island; H, ?Mesoproterozoic Rocky Cape Block; I, Macquarie Harbour. Circle, Peebinga-1 drillhole location. (b) Geometry of bathymetry and volcanic provinces associated with the west-facing Mid-Jurassic (Oxfordian) to early Cretaceous (Hauterivian) rifted margin of NW Australia. Depths in kilometres. After Crawford \& von Rad (1994) and Planke et al. (1999). Approximate continent-ocean boundary (COB) shown in red. 


\section{New South Wales and South Australia}

In the Mt Arrowsmith region of western New South Wales ('B' in Fig. 1a), a $5 \mathrm{~km}$ thick, vertically dipping, thickly layered sequence of dominantly basaltic volcanic and volcaniclastic rocks, and interbedded marine sedimentary rocks parallels the NW-striking eastern margin of the Early to Mid-Proterozoic Curnamona Craton. Lava compositions range from olivine-rich transitional alkaline basalts to rift tholeiitic basalts; more evolved trachytic and comenditic lavas are rare, and one yielded a sensitive high-resolution ion microprobe (SHRIMP) U-Pb zircon date of $586 \pm 7 \mathrm{Ma}$ (Crawford et al. 1997). Olivine-phyric basalts make up a significant proportion of the exposed volcanic pile at Mt Arrowsmith, and although picritic lavas are not represented, olivine-dominated cumulate rocks occur in small plugs and fault slices (Edwards 1980). Similar basalts occur along this belt further SE at Mt Wright (' $\mathrm{C}$ ' in Fig. 1a). Geophysical modelling indicated that large volumes of these volcanic rocks exist at depth, producing elongate long-wavelength magnetic highs (Fig. 1a) (Direen 1998). Overall, the subsurface mafic volcanic pile is best modelled as subhorizontal and NE-dipping, but in places these rocks are brought to the surface by listric thrust faults and crop out as near-vertically dipping slices (Direen 1998).

The major magnetic trends defined by these volcanic rocks in western New South Wales (Fig. 1a) wrap around the Curnamona Craton, to reappear again in easternmost South Australia. In the
Truro area of South Australia ('E' in Fig. 1a), poorly exposed basaltic to trachytic volcanic and volcaniclastic rocks are interbedded with metamorphosed limestones and siltstones (Forbes et al. 1972) and have also been intersected in stratigraphic drillholes (Gatehouse et al. 1991). Crawford et al. (1997) showed a pronounced geochemical and $\mathrm{Nd}$ isotopic similarity between the Truro Volcanics and the c. $590 \mathrm{Ma}$ basalts exposed at $\mathrm{Mt}$ Arrowsmith and Mt Wright, supported by further trace element geochemistry reported by Direen (1998). Geochemically, these basalts are all transitional alkaline rocks showing within-plate signatures (e.g. $\mathrm{Zr} / \mathrm{Nb}$ values generally $<10$ ) and moderate LREE enrichment (Fig. 2a). Basalt compositions are typical of those in young rifts such as the early Red Sea-Afar RiftGregory Rift-Gulf of Tadjoura region (Crawford et al. 1997).

\section{Western Victoria and South Australia}

Drilling near the northwestern termination of the Dimboola Subzone (VandenBerg et al. 2000), a large magnetic high extending NNW across western Victoria ('F' in Fig. 1a) has, intersected magnetized pillowed rift tholeiitic to transitional alkaline basalts, intercalated with limestones and volcaniclastic rocks (Rankin et al. 1991). Geophysical modelling (Direen \& Crawford 1998; Direen 1999) using magnetic susceptibilities of the drilled rocks $\left(c .2000 \times 10^{-5} \mathrm{SI}\right)$ suggests that these mafic volcanic rocks extend southward at a depth of at least $1 \mathrm{~km}$ below Palaeozoic and Cenozoic sediments, and that they are
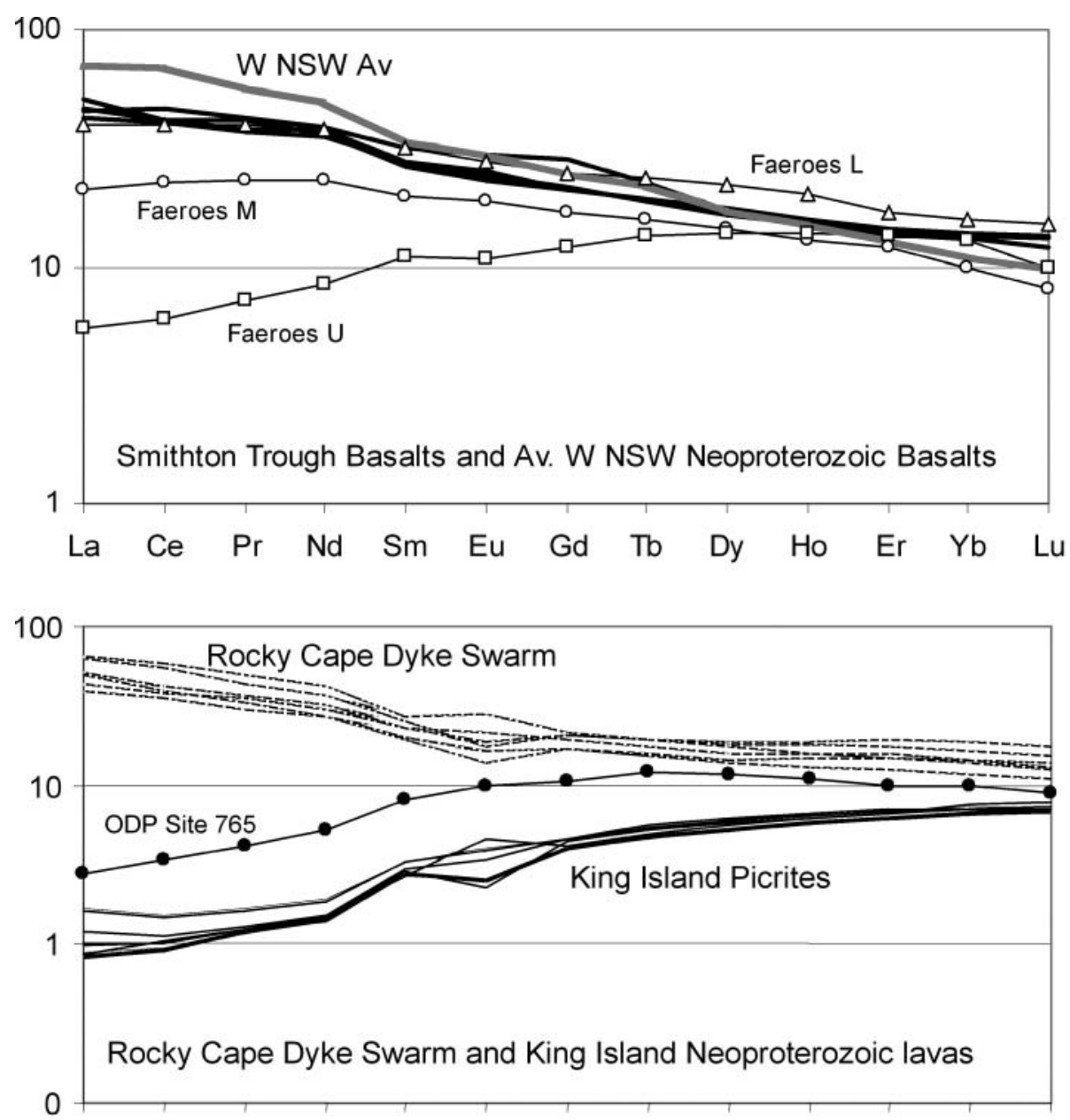

La Ce Pr Nd Sm Eu Gd Tb Dy Ho Er Yb Lu
Fig. 2. Representative chondrite-normalized (Sun \& McDonough 1989) REE patterns. (a) Rift tholeiites from the Neoproterozoic sections of SE Australia including western New South Wales (wide shaded line) and Smithton Trough (continuous bold lines) in W Tasmania, and representative break-up basalts from the Faeroes Islands drilled in ODP Leg 152 (Saunders et al. 1997). $\square$, Upper Faeroes, least contaminated, primitive high-MgO ol-basalts, picrites; $\bigcirc$, Middle Faeroes, evolved (mixed mantlecrust melts) basalts, dacites, acidic pyroclastic rocks; $\triangle$, Lower Faeroes, crustally contaminated basalts, ol-basalts, picrites. (b) The 600 Ma Rocky Cape dyke swarm dolerites from NW Tasmania (dashed lines), c. 600 Ma King Island picrites (continuous lines), and a depleted MORB drilled just seaward of the break-up off NW Australia at ODP Site $765(\bullet)$ (Ludden \& Dionne 1992). 
responsible for the longer wavelength component of the major magnetic high. A second shorter wavelength component is attributed to younger overthrust slivers of calc-alkaline andesitedacite lavas, volcaniclastic rocks, and serpentized metagabbroids, as intersected in shallow drillholes (Maher et al. 1997). Drilling of magnetic anomalies c. $25 \mathrm{~km}$ west of the main magnetic high in western Victoria yielded distinctive low- $\mathrm{TiO}_{2}$ serpentinized picritic lavas and cumulates. The rocks of this suite are not amenable to dating, but their age is broadly constrained by the age of orthogneisses they are interpreted to overlie, which formed between c. 1030 and $589 \mathrm{Ma}$, and the c. $501 \mathrm{Ma}$ metamorphic age of the gneisses (Maher et al. 1997). Wholerock (Maher et al. 1997) and chromite geochemistry (Direen \& Crawford 2003) suggests that these rocks have greatest affinity with picrites found on King Island (Waldron et al. 1993), which have a latest Neoproterozoic age (see below).

\section{Tasmania}

The southernmost major belt of late Neoproterozoic mafic volcanic rocks is associated with an arcuate magnetic high that extends from the southern coastline of mainland Australia across Bass Strait, and wraps around the western edge of Tasmania (' $G$ ' in Fig. 1a). Mafic volcanic rocks on this trend crop out on eastern King Island, with exposures including dykes, pillow lavas, volcaniclastic rocks and dolomites. Waldron et al. (1993) divided this sequence into three packages based on volcanic facies and geochemistry. The upper and lower packages are rift tholeiites, whereas the middle package, containing both subaerial and subaqueous facies, comprises a relatively thick sequence of distinctive, formerly glassy, picritic lavas with up to $22 \% \mathrm{MgO}$. The basalt-picrite package is inferred from magnetic modelling to be present in large volumes offshore (Direen \& Crawford 2003).

Lavas and dykes with transitional alkaline to rift tholeiitic compositions also occur widely over western Tasmania (Crawford \& Berry 1992). The Rocky Cape dyke swarm, trending NNE over the Mid-Proterozoic Rocky Cape Block, gives $\mathrm{K}-\mathrm{Ar}$ dates at $588 \pm 8 \mathrm{Ma}$ and $600 \pm 8 \mathrm{Ma}$ (Brown 1986). Rift tholeiitic basalts also occur within a thick dolomitic package in the Togari Group of the Smithton Trough in northwestern Tasmania, above a pronounced break-up unconformity. Carbonate chemostratigraphy on the interbedded dolomites suggests late Cryogenian to early Neoproterozoic III ages, or c. 650-580 Ma (Calver 1998). A volcanic sequence at Double Cove on the western coast of Tasmania is close to $1 \mathrm{~km}$ thick, and comprises massive and pillowed basalts with rift tholeiitic compositions, interbedded with subordinate mudstones. Farther east, lavas and dykes of the Crimson Creek Formation in the Dundas Trough match the Togari Group and Double Cove lavas lithostratigraphically and compositionally (Crawford \& Berry 1992), but also include basalts closer to N-MORB compositions.

The King Island and Double Cove picrites are compositionally unusual, with $\mathrm{TiO}_{2}<0.3 \%$ at $12 \% \mathrm{MgO}$, and very strongly LREE-depleted chondrite-normalized REE patterns (Fig. 2b: $\mathrm{La}_{\mathrm{N}} / \mathrm{Sm}_{\mathrm{N}}$ c. 0.3; Waldron et al. 1993). The picritic lavas and cumulates drilled in westernmost Victoria are compositionally very similar, with low $\mathrm{TiO}_{2} \quad(<0.2 \%$ at $22 \% \mathrm{MgO})$ and pronounced LREE depletion (Fig. 2). To date, no basalts as strongly depleted as the King Island-type picrites have been reported from younger (in situ) SDRS packages. However, lavas drilled close to the continent-ocean transition on the northwestern Australian margin (Fig. 1b), and associated with the onset of sea-floor spreading, are notably more depleted than typical N-MORB (Ludden \& Dionne 1992). Similarly, strongly depleted N-MORB (Fig. 2b) were drilled at ODP Site 917 on the SDRS pile along the east Greenland margin (Saunders et al. 1997).

\section{Discussion}

Modelling of long-wavelength, high-amplitude gravity and magnetic highs spatially coincident with thick, reworked volcanic piles in New South Wales, western Victoria and King Island indicates common geometry and structural style (Direen 1998; Direen \& Crawford 1998, 2003). The volcanic rocks form eastdipping wedges $1.5-6 \mathrm{~km}$ thick, with strike lengths of 200$240 \mathrm{~km}$. These dimensions are commensurate with SDRS described on the Møre-Vøring and the Exmouth-Cuvier volcanic margins. On the basis of these geophysical and petrologicalgeochemical similarities, we believe that the Late Neoproterozoic volcanic piles in southeastern Australia are fossil seawarddipping reflector sequences.

Finn et al. (1999) proposed an alternative arc-derived source for the magnetic high in western Victoria. Detailed petrophysical data (Direen 1999) indicated that the calc-alkaline volcanic rocks proposed by Finn et al. (1999) as the source of the magnetic anomalies have magnetic susceptibilities two orders of magnitude less than rift-related volcanic sources invoked here. It is thus unlikely that the model proposed by Finn et al. (1999) is correct, and we prefer a model that invokes large volumes of highly magnetic SDRS basalts as the source of the major magnetic anomalies in southeastern Australia, and, as indicated by Finn et al. (1999), in Northern Victoria Land in Antarctica.

We argue that the common ages, eruption environments and enclosing marine sequences seen in these mafic volcanic belts in southeastern Australia represent sectors of a single latest Neoproterozoic volcanic passive margin. The preserved remnants of this system now form rigid, often fault-bounded wedges in a more complicated crustal collage related to later collisional events. In terms of their geological occurrence, associated sedimentary packages and transitional alkaline to rift tholeiite compositions, the more westerly magmatic suites represented among the $c$. $600 \mathrm{Ma}$ suites in southeastern Australia are indicative of an evolving rift in continental crust. Farther east, the abundance of rift tholeiites and associated high-temperature picritic lavas suggests proximity to break-up and formation as part of a Neoproterozoic SDRS package. A possible modern analogue is the Mesozoic Cuvier-Exmouth margin (Fig. 1b), where orthogonality and scales of the SDRS segments match well those of the Neoproterozoic margin, and typical rift tholeiites occur nearer the continent and more depleted compositions (including the highly depleted Site 765 tholeiites: Ludden \& Dionne 1992) further seaward. Massive seaward-dipping reflector packages immediately precede break-up (Fig. 1b) on this margin (Colwell et al. 1994; Symonds et al. 1998).

The geochemical characteristics of the Neoproterozoic picrites, and their occurrence in these sequences at or close to the top of the volcanic packages, suggest that they were generated from residues of melting events that produced underlying tholeiites, probably from the top of melting columns that were being abandoned as rifting and magma supply jumped eastward to more favourable locations. This is analogous to the temporal and spatial controls on the distribution of picrites in SDRS reported from SE Greenland (Fitton et al. 2000).

Although undoubtedly affected by Early Palaeozoic tectonism (Direen 1998), the consistent geometries of these c. $600 \mathrm{Ma}$ magmatic suites, with more alkaline lavas in the west and thicker, more MORB-like basalt piles in the east, suggest that 
ocean opening eventually occurred east of the present location of these packages. This is supported by the occurrence further to the east in Victoria and Tasmania of forearc-derived ophiolites, which were emplaced from east to west during Early MidCambrian arc-continent collision onto the leading edge of the rifted volcanic passive margin crust (Crawford \& Berry 1992). However, the elongate (at least $3000 \mathrm{~km}$ ) narrow nature of these thick, c. $600 \mathrm{Ma}$ basalt sequences, coupled with their orthogonal distribution and sharp bends around cratonic nuclei, is still remarkably similar in plan to the disposition of the Mesozoic SDRS along the Cuvier-Exmouth volcanic passive margin (Fig. 1b), suggesting that the fossil continent-ocean transition is not too distant from their present location.

\section{Tectonic implications}

The recognition of a major rifting event in the southeastern sector of Gondwanaland at c. $600 \mathrm{Ma}$ has profound implications for reconstructions of Rodinia (Veevers 2000). Recent palaeomagnetic work on Rodinia break-up has focused on scattered occurrences of mafic intrusive rocks ranging in age between $777 \pm 7$ and $755 \pm 3 \mathrm{Ma}$ but with assumed related volcanic rocks stretching back to $827 \pm 9 \mathrm{Ma}$ (Wingate et al. 1998, 2001). The difficulty in defining a clear-cut pulse of magmatism related to the postulated Rodinian break-up, and thus defining a conjugate margin for testing of continental blocks within different supercontinent reconstructions (e.g. Gose et al. 1997; Burrett \& Berry 2000) can be directly attributed to the break-up event at c. $600 \mathrm{Ma}$. This is because the passive margin formed by the hypothetical earlier break-up must have either been obliterated by the extensive pulse of flood basalt-rift volcanism at $c$. $600 \mathrm{Ma}$, or alternatively, it was rifted away into the PalaeoPacific at this time. This second situation may be analogous to Mesozoic passive margin sequences preserved on the Lord Howe Rise and Norfolk-New Caledonia Rise east of Australia, both of which rifted off Australia in the Late Cretaceous (Müller et al. 2000). A third, contentious alternative is that there was no Rodinian continental break-up prior to $c$. $600 \mathrm{Ma}$.

It could be argued that later (Silurian and Devonian) convergence that contributed to formation of the Lachlan Orogen of eastern Australia may have returned the block carrying the record of the postulated older (c. 827-755 Ma) break-up as an 'exotic' terrane. In particular, there is a possibility that it may have underthrust the east part of the Lachlan Orogen, where crustal thicknesses in excess of $50 \mathrm{~km}$ occur beneath the Snowy Mountains (Finlayson et al. 1993), to become the source for some of the widespread S- and I-type granites of the Lachlan Orogen (e.g. Collins 1998). However, this hypothesis is in disagreement with analysis of inherited zircon populations in the S-type granites (Williams et al. 1992; Veevers 2000). The dominant population comprises $650-450 \mathrm{Ma}$ zircons, with no known inherited zircon population matching the currently accepted timing of the hypothetical Rodinia break-up around $827-$ $780 \mathrm{Ma}$ (older populations being recognized only at 1100 and $1000 \mathrm{Ma})$. We concur with Collins (1998) in arguing that the source of the $600 \mathrm{Ma}$ inherited zircons in the Lachlan Orogen turbidite pile may be expressions of even greater volumes of Neoproterozoic crustal melting as a result of c. 600 Ma break-up magmatism, concealed within a mid- to deep crustal terrane beneath the Lachlan Orogen.

It thus appears that the rifted block carrying the record of the postulated Rodinian break-up in southeastern Gondwanaland may never have been returned, and may now reside elsewhere along the Palaeo-Pacific Rim. Thus, evidence for volcanism associated with the Rodinia break-up should be sought elsewhere. Alternatively, there may never have been a Rodinia breakup event on this margin between 827 and $780 \mathrm{Ma}$, and eastern Gondwanaland may have faced the Pacific since at least that time, with episodic calving off of narrow continental ribbons, such as the Lord Howe Rise, one or more of which may have returned to collide with Palaeozoic arc systems during the extended formation of the early and mid-Palaeozoic Lachlan Orogen (Glen et al. 2002).

N.G.D. acknowledges an AGSO Postgraduate Award, and financial support from Mineral Resources New South Wales. A.J.C. gratefully acknowledges financial support from ARC grants. Thoughtful and constructive reviews by J. Veevers, G. Fitton and P. Cawood enhanced the manuscript. The Geological Survey of Victoria is thanked for permission to use and modify material in Figure 1.

\section{References}

BARKeR, P.F. 1999. Evidence for a volcanic rifted margin and oceanic crustal structure for the Falkland Plateau Basin. Journal of the Geological Society, London, 156, 889-900.

Brown, A.V. 1986. Geology of the Dundas-Mt Lindsay-Mt Ramsay Area. Geological Survey of Tasmania Bulletin, 62

Burrett, C.F. \& Berry, R.F. 2000. Proterozoic Australia-Western United States (AUSWUS) fit between Laurentia and Australia. Geology, 28, 103-106.

CAlver, C.R. 1998. Isotope stratigraphy of the Neoproterozoic Togari Group, Tasmania. Australian Journal of Earth Sciences, 45, 865-874.

Collins, W.J. 1998. Evaluation of petrogenetic models for Lachlan Fold Belt granitoids: implications for crustal architecture and tectonic models. Australian Journal of Earth Sciences, 45, 483-500.

Colwell, J.B., Symonds, P.A. \& Crawford, A.J. 1994. The nature of the Wallaby (Cuvier) Plateau and other igneous provinces of the West Australian margin. AGSO Journal of Australian Geology and Geophysics, 15, 137-156.

Crawford, A.J. \& Berry, R.F. 1992. Tectonic implications of Late ProterozoicEarly Palaeozoic igneous rock associations in western Tasmania. Tectonophysics, 214, 37-56.

Crawford, A.J. \& von RAD, U. 1994. The petrology and implications of basalts dredged from the Rowley Terrace-Scott Plateau and Exmouth Plateau margins, northwestern Australia. AGSO Journal of Australian Geology and Geophysics, 15, 43-54.

Crawford, A.J., Stevens, B.P.J. \& Fanning, M. 1997. Geochemistry and tectonic setting of some Neoproterozoic and Early Cambrian volcanics in western New South Wales. Australian Journal of Earth Sciences, 44, 831-852.

Direen, N.G. 1998. The Palaeozoic Koonenberry Fold and Thrust Belt, far western New South Wales: a case study in applied gravity and magnetic modelling. Exploration Geophysics, 50, 491-502.

Direen, N.G. 1999. Geology and geophysics of the Koonenberry Belt, far western New South Wales, and eastern Australian correlates. PhD thesis, University of Tasmania Hobart.

Direen, N.G. \& Crawford, A.J. 1998. Evidence for the timing of continental breakup and volcanic passive margin formation, southeast Gondwana: an actualistic perspective. In: BIRD, R.T. (ed.) The Assembly and Breakup of Rodinia. Geological Society of Australia Abstracts, 50, 24-28.

Direen, N.G. \& Crawford, A.J. 2003. The Tasman Line: where is it, what is it, and is it Australia's Rodinian breakup boundary? Australian Journal of Earth Sciences, 50, 491-501.

EDWARDS, A.C. 1980. The geology and petrology of the igneous rocks of Mt. Arrowsmith and related areas of northwestern New South Wales. $\mathrm{PhD}$ thesis, University of New South Wales.

Eldholm, O., Thiede, J. \& TAYlor, E. 1989. The Norwegian continental margin: tectonic, volcanic and palaeoenvironmental framework. In: ELDHOLM, O., Thiede, J. \& TAylor, E. ET AL. (eds) Proceedings of the Ocean Drilling Program, Scientific Results, 104. Ocean Drilling Program, College Station, TX, 5-26.

EXON, N.F., HAQ, B.U. \& vON RAD, U 1992. Exmouth plateau revisited: scientific drilling and geological framework. In: vON RAD \& HAQ, B.U. ET AL. (eds) Proceedings of the Ocean Drilling Program, Scientific Results, 122, 3-20.

Finlayson, D.M., Owen, A.J., Johnstone, D.W. \& Wake-Dyster, K.D. 1993. Moho and petrologic crust-mantle boundary coincide under southeastern Australia. Geology, 21, 707-710.

Finn, C., Moore, D., Damaske, D. \& Mackey, T. 1999. Aeromagnetic legacy of early Palaeozoic subduction along the Pacific margin of Gondwana. Geology, 27, 1087-1090. 
Fitton, J.G., Larsen, L.M., Saunders, A.D., Hardarson, B.S. \& Kempton, P.D. 2000. Palaeogene continental to oceanic magmatism on the SE Greenland continental margin at $63^{\circ} \mathrm{N}$ : a review of the results of Ocean Drilling Program Legs 152 and 163. Journal of Petrology, 41, 951-966.

Foden, J., Barovich, K., Jane, M. \& O'Halloran, G. 2001. Sr-isotopic evidence for Late Neoproterozoic rifting in the Adelaide Geosyncline at $586 \mathrm{Ma}$ : implications for a $\mathrm{Cu}$ ore-forming fluid flux. Precambrian Research, 106, 291-308.

Forbes, B.G., Coats, R.P. \& Daily, B. 1972. Truro volcanics. Quarterly Notes of the Geological Survey of South Australia, 44, 1-5.

Francis, D., Ludden, J. \& Hynes, A. 1983. Magma evolution in a Proterozoic rifting environment. Journal of Petrology, 24, 556-582.

Gatehouse, C.G., McCulloch, A.J., Clough, B.J. \& Sarunic, W. 1991. Mount Rufus-1 Well Completion Report. Department of Mines and Energy South Australia Unpublished Report Book, 91/25.

Gladczenko, T.P., Hinz, K., Eldholm, O., Meyer, H., Neben, S. \& Skogseid, J. 1997. South Atlantic volcanic margins. Journal of the Geological Society, London, 154, 465-470.

Glen, R.A., Korsch, R.J. \& Direen, N.G. ET AL. 2002. Crustal structure of the Ordovician Macquarie Arc, eastern Lachlan Orogen, based on seismic reflection profiling: responses to contractional and extensional deformation. Australian Journal of Earth Sciences, 49, 323-348.

Gose, W.A., Helper, M.A., Connely, J., Hutson, F. \& Dalziel, I.W.D. 1997. Paleomagnetic results and $\mathrm{U}-\mathrm{Pb}$ isotopic ages from Coats Land, Antarctica: a test of the SWEAT hypothesis. Journal of Geophysical Research, 104, 7887-7902.

Larsen, H.C., Dahl-Jensen, T. \& Hopper, J.R. 1998. Crustal structure along the Leg 152 drilling transect. In: SAunders, A.D., LARSEN, H.C. \& Wise, S.W. $\mathrm{J}_{\mathrm{R}}$ (eds) Proceedings of the Ocean Drilling Program Scientific Results, 152. Ocean Drilling Program, College Station, TX, 463-475.

LI, Z.X. \& Powell, C.MCA. 2001. An outline of the palaeogeographic evolution of the Australasian region since the beginning of the Neoproterozoic. EarthScience Reviews, 53, 237-277.

Ludden, J.N. \& Dionne, B. ET AL. 1992. The geochemistry of oceanic crust at the onset of rifting in the Indian Ocean. In: Gradstein, F.M. \& LudDEN, J.N. (eds) Proceedings of the Ocean Drilling Program Scientific Results, 123. Ocean Drilling Program, College Station, TX, 791-799.

Maher, S., Moore, D.H., Crawford, A.J., Twyford, R. \& Fanning, C.M. 1997. Test Drilling of the Southern Margin of the Murray Basin. Victorian Initiative for Minerals and Petroleum Report, 52.

Meixner, A.J., Boucher, R.K., Yeates, A.N., Frears, R.A., GunN, P.J. \& RichaRdSON, L.M. 1999. Interpretation of Geophysical and Geological Data Sets, Cooper Basin Region, South Australia. AGSO Record, 1999/22.

Mjelde, R., Digranes, P. \& Van SchaAcK, M. et AL. 2001. Crustal structure of the outer Vøring Plateau, offshore Norway, from ocean bottom seismic and gravity data. Journal of Geophysical Research, 106, 6769-6791.

Müller, R.D., Gaina, C. \& Clark, S. 2000. Seafloor spreading around Australia. In: Veevers, J.J. (ed.) Billion-year Earth History of Australia and Neighbours in Gondwanaland. GEMOC Press, Sydney, N.S.W., 18-28.

Planke, S., Cerney, B., Bücker, C.J. \& Nilsen, O. 1999. Alteration effects on petrophysical properties of subaerial flood basalts: Site 990, Southeast Greenland margin. In: Larsen, H.C., Duncan, R.A., Allen, J.F. \& Brooks, K. (eds) Proceedings of the Ocean Drilling Program Scientific Results 163. Ocean Drilling Program, College Station, TX, 17-28.

Planke, S., Symonds, P.A., Alvestad, E. \& Skogseid, J. 2000. Seismic volcanostratigraphy of large volume basaltic extrusive complexes on rifted margins. Journal of Geophysical Research, 105, 19335-19351.

Rankin, L.R., Clough, B.J., Farrand, M.G., Barnett, S., Lablack, K., Gatehouse, C.G. \& Hough, L.P. 1991. Murray Basin Basement Transect Project: 1990 Well Completion Reports. Department of Mines and Energy, South Australia, Unpublished Report, 91/15.

Saunders, A.D., Fitton, J.G., Kerr, A.C., Norry, M.J. \& Kent, R.W. 1997. The North Atlantic Igneous Province. In: Mahoney, J.J. \& Coffin, M.F. (eds)
Large Igneous Provinces: Continental, Oceanic, and Planetary Flood Volcanism. Geophysical Monograph, American Geophysical Union, 100, 45-86.

Saunders, A.D., Larsen, H.C. \& FitTon, J.G. 1998. Magmatic development of the southeast Greenland margin and evolution of the Iceland plume: geochemical constraints from Leg 152. In: SAUnders, A.D., LARSEN, H.C. \& Wise, S.W. JR (eds) Proceedings of the Ocean Drilling Program Scientific Results, 152. Ocean Drilling Program, College Station, TX, 479-501.

Sayers, J., Symonds, P.A., Direen, N.G. \& Bernardel, G. 2001. Nature of the continent-ocean transition on the non-volcanic rifted margin of the central Great Australian Bight. In: Wilson, R.C.L., Whitmarsh, R.B., TAYlor, B. \& Froitzheim, N. (eds) Non-volcanic Rifting of Continental Margins: a Comparison of Evidence from Land and Sea. Geological Society, London, Special Publications, 187, 51-77.

St-Onge, M.R., Lucas, S.B., Scott, D.J. \& Wodicka, N. 1999. Upper and lower plate juxtaposition, deformation and metamorphism during crustal convergence, Trans-Hudson Orogen (Quebec-Baffin segment), Canada. Precambrian Research, 93, 27-49.

Skogseid, J., Pedersen, T., Eldholm, O. \& Larsen, B.T. 1992. Tectonism and magmatism during N.E. Atlantic continental break-up: the Vøring Margin. In: Storey, B.C., Alabaster, T. \& Pankhurst, R.J. (eds) Magmatism and the Causes of Continental Break-up. Geological Society, London, Special Publications, 68, 305-320.

Sun, S.S. \& McDonough, W.F. 1989. Chemical and isotopic systematics of oceanic basalts: implications for mantle composition and processes. In: SAunders, A.D. \& Norry, M.J. (eds) Magmatism in Ocean Basins. Geological Society, London, Special Publications, 42, 313-345.

Symonds, P.A., Planke, S., Frey, O. \& Skogseid, J. 1998. Volcanic evolution of the Western Australian continental margin and its implications for basin development. In: Purcell, P.G. \& Purcell, R.R. (eds) The Sedimentary Basins of Western Australia 2. Proceedings of Petroleum Exploration Society of Australia Symposium, Perth, WA. 2, 33-54.

Talwani, M., Ewing, J., Sheridan, R.E., Holbrook, W.S. \& Glover, L. 1995. The EDGE experiment and the U.S. East Coast Magnetic Anomaly. In: Banda, E., Torne, M. \& Talwani, M. (eds) Rifted Ocean-Continent Boundaries. Kluwer, Dordrecht, 155-181.

Vandenberg, A.H.M., Willman, C.E. \& Maher, S. ET AL. 2000. The Tasman Fold Belt System in Victoria. Geological Survey of Victoria Special Publication.

VeEvers, J.J. (ED.) 2000. Billion-year Earth History of Australia and its Neighbours in Gondwanaland. GEMOC Press, Sydney, N.S.WÒ

Veevers, J.J., Walter, M.R. \& Scheibner, E. 1997. Neoproterozoic tectonics of Australia-Antarctica and the $560 \mathrm{Ma}$ birth of the Pacific Ocean reflect the 400 m.y. Pangaean Supercycle. Journal of Geology, 105, 225-242.

Viereck, L.G., Taylor, P.N., Parson, L.M., Morton, A.C., Hertogen, J., Gibson, I.L., \& The ODP Leg io4 Scientific Party 1988. Origin of the Palaeogene Vøring Plateau volcanic sequence. In: Morton, A.C. \& PARson, L.M. (eds) Early Tertiary Volcanism and the Opening of the NE Atlantic. Geological Society, London, Special Publications, 39, 69-83.

Waldron, H.M., Brown, A.V. \& Keays, R.R. 1993. Geological Setting and Petrochemistry of EocambrianCambrian Volcano-sedimentary Rock Sequences from Southeast King Island. Mineral Resources Tasmania Report, $1993 / 28$.

Williams, I.S., Chappell, B.W., Chen, Y.D. \& Crook, K.A.W. 1992. Inherited and detrital zircons - vital clues to the granite protoliths and early igneous history of southeastern Australia. Transactions of the Royal Society of Edinburgh, Earth Sciences, 83, 503.

Wingate, M.T.D., Campbell, I.H., Compston, W. \& Gibson, G.M. 1998. Ion microprobe $\mathrm{U}-\mathrm{Pb}$ ages for Neoproterozoic basaltic magmatism in southcentral Australia and implications for the breakup of Rodinia. Precambrian Research, 87, 135-159.

Wingate, M.T.D., Pisarevsky, S.A. \& Evans, D.A.D. 2001. A revised Rodinia supercontinent: no SWEAT, no AUSWUS. Terra Nova, 14, 121-128. 